OPEN ACCESS

Edited by: Karin Albornoz,

University of Concepcion, Chile

Reviewed by:

Spurthi N. Nayak,

University of Agricultural Sciences,

Dharwad, India

Chenggen Chu,

Edward T. Schafer Agricultural Research Center (USDA-ARS),

United States

*Correspondence:

Seonghee Lee

seonghee105@ufl.edu

tThese authors have contributed equally to this work

Specialty section: This article was submitted to Plant Genomics,

a section of the journal

Frontiers in Genetics

Received: 25 June 2021 Accepted: 30 July 2021 Published: 24 August 2021

Citation:

Chandra S, Oh Y, Han H, Salinas N, Anciro A, Whitaker VM, Chacon JG, Fernandez $G$ and Lee $S$ (2021) Comparative Transcriptome Analysis to Identify Candidate Genes for FaRCg1 Conferring Resistance

Against Colletotrichum gloeosporioides in Cultivated Strawberry (Fragaria $\times$ ananassa).

Front. Genet. 12:730444. doi: 10.3389/fgene.2021.730444

\section{Comparative Transcriptome Analysis to Identify Candidate Genes for FaRCg1 Conferring Resistance Against Colletotrichum gloeosporioides in Cultivated Strawberry (Fragaria $\times$ ananassa)}

\author{
Saket Chandra ${ }^{1 \dagger}$, Youngjae $\mathrm{Oh}^{1 \dagger}$, Hyeondae Han ${ }^{1}$, Natalia Salinas ${ }^{1}$, Ashlee Anciro', \\ Vance M. Whitaker ${ }^{1}$, Jose Guillermo Chacon ${ }^{2}$, Gina Fernandez ${ }^{2}$ and Seonghee Lee ${ }^{1 *}$ \\ ${ }^{1}$ Department of Horticultural Sciences, University of Florida-IFAS Gulf Coast Research and Education Center, Wimauma, FL, \\ United States, ${ }^{2}$ Department of Horticultural Sciences, North Carolina State University, Raleigh, NC, United States
}

Colletotrichum crown rot (CCR) caused by Colletotrichum gloeosporioides is a serious threat to the cultivated strawberry (Fragaria $\times$ ananassa). Our previous study reported that a major locus, FaRCg1, increases resistance. However, the genomic structure of FaRCg1 and potential candidate genes associated with the resistance remained unknown. Here, we performed comparative transcriptome analyses of resistant 'Florida Elyana' and susceptible 'Strawberry Festival' after infection and identified candidate genes potentially involved in resistance. In 'Florida Elyana', 6,099 genes were differentially expressed in response to $C$. gloeosporioides. Gene ontology analysis showed that the most upregulated genes were functionally associated with signaling pathways of plant defense responses. Three genes in the genomic region of FaRCg1 were highly upregulated: a von Willebrand Factor A domain-containing protein, a subtilisin-like protease, and a TIFY 11A-like protein. Subgenome-specific markers developed for the candidate genes were tested with a diverse panel of 219 accessions from University of Florida and North Carolina State University breeding programs. Significant and positive associations were found between the high-resolution melting (HRM) marker genotypes and CCR phenotypes. These newly developed subgenome-specific functional markers for FaRCg1 can facilitate development of resistant varieties through marker-assisted selection.

Keywords: quantitative trait locus, DNA marker, high-resolution melting, octoploid strawberry, RNA sequencing

\section{INTRODUCTION}

Colletotrichum species are some of the most notorious and damaging diseases of the cultivated strawberry worldwide (Münch et al., 2008). Colletotrichum gloeosporioides is a necrotrophic fungi that causes Colletotrichum crown rot (CCR) of strawberry (Fragaria $\times$ ananassa), which is an important disease in Florida and throughout the southeastern United States. The necrotic 
infections in crown tissues cause necrosis, plant collapse, and death in hot and humid conditions (MacKenzie et al., 2006; Rahman and Louws, 2017). Most commercial cultivars currently grown in the United States are susceptible to CCR and, thus, economic losses occur nearly every season from this disease. Both curative (pyraclostrobin, strobilurins, and azoxystrobin) and preventive (captan) fungicides are commonly used to control CCR, but chemical controls are not very effective once plants become infected (MacKenzie et al., 2009; Rahman and Louws, 2017). The use of resistant varieties would be the most robust and economically viable way to control this disease. Therefore, deciphering resistance genes and understanding their role in CCR resistance would help facilitate the development of resistant varieties.

In a previous study, a major locus, FaRCgl, conferring resistance to CCR was identified using two large multi-parental populations (Anciro et al., 2018). This locus was responsible for most of the genetic variation for resistance against C. gloeosporioides in breeding populations. To introduce this resistance locus effectively via marker-assisted breeding, it is critical to have subgenome-specific markers that are closely associated with FaRCg1. However, the genomic region of FaRCg1 has not yet been characterized, and no candidate genes linked to resistance have been identified. Functional markers would have the potential to greatly enhance resistance breeding via maker-assisted selection (MAS) in the cultivated strawberry (Noh et al., 2018; Oh et al., 2020).

The genome of octoploid cultivated strawberries $(2 n=8 \times=56)$ is highly heterozygous and complex. The modern allo-octoploid strawberry was formed by the interaction and fusion of genomes originating from four different diploid ancestors (Fragaria vesca, Fragaria iinumae, Fragaria viridis, and Fragaria nipponica; Edger et al., 2019). Because of these four sub-genomes, understanding the genomic structures of known quantitative trait locus (QTL) is difficult without DNA sequencing data from multiple strawberry accessions. Previously, the Axiom ${ }^{\circledR}$ IStraw90 and IStraw35 SNP arrays were developed for accelerating QTL discovery and marker-assisted selection by using sequencing information from the F. vesca genome (Bassil et al., 2015; Verma et al., 2016). However, most of the SNP probe sequences from IStraw90 and IStraw35 arrays were not subgenome-specific and it was difficult to accurately locate their physical marker locations in the octoploid genome (Whitaker et al., 2020). To resolve this problem, the FanaSNP array, with 50,000 subgenome-specific SNPs, has been developed from the recently published reference genome (Hardigan et al., 2020). The availability of this new SNP array has accelerated the identification of genes and loci controlling important traits for disease resistance and fruit quality in the cultivated strawberry (Barbey et al., 2021; Hardigan et al., 2021; Oh et al., 2021).

The plant-pathogen interaction at the molecular level between octoploid strawberry and C. gloeosporioides has not been well-understood. Dissecting transcriptome data between resistant and susceptible cultivated strawberries after the pathogen infection could facilitate discovery of candidate genes associated with resistance against C. gloeosporioides. Using RNA-seq methods, several studies showed possible functional mechanisms and signaling cascades associated with defense responses against multiple pathogens in strawberry and other crops (Xu et al., 2011; Schenk et al., 2012; Gao et al., 2013; Liu et al., 2015; Tan et al., 2015). Transcriptome studies were also carried out to delineate differentially expressed genes (DEGs) related to the defense responses against two important strawberry crown rot pathogens, Phytophthora cactorum and C. gloeosporioides (Toljamo et al., 2016; Wang et al., 2017; Zhang et al., 2018). Previous transcriptome analysis with several strawberry cultivars, 'Yanli', 'Toyonoka,' 'Sachinoka', and 'Benihoppe', revealed gene expression changes in response to C. gloeosporioides. A number of genes associated with pathogen-associated molecular patterns (PAMs) and effectortriggered immunity were highly expressed for the resistance response (Wang et al., 2017). In another study, genes differentially expressed in response to the pathogen C. gloeosporioides were determined with two different cultivars 'JiuXiang' and 'Sweet Charlie' (Zhang et al., 2018). The transcriptome analysis revealed that genes such as chitin elicitor receptor kinase 1, enhanced disease susceptibility 1 , cyclic nucleotide gated-ion channel, WRKY33, disease resistance protein RPM1, calcium-dependent protein kinase, respiratory burst oxidase homolog, Calmodulin, and pathogenesis-related protein 1 , are all closely associated with resistance against C. gloeosporioides in strawberry (Wang et al., 2017; Zhang et al., 2018). It was also shown that exogenous application of salicylic acid directly inhibits the germination of the pathogen and induces NB-LRR R-genes (Zhang et al., 2018). Until now, however, there is no study identifying candidate genes in known QTL regions associated with resistance to C. gloeosporioides in cultivated strawberry. Candidate genes for FaRCg1 could be extremely valuable for developing subgenome-specific markers.

In the present study, RNA-seq has been employed to understand transcriptional regulation as well as to decipher potential candidate genes for $\mathrm{FaRCg} 1$-mediated resistance against C. gloeosporioides in the octoploid cultivated strawberry. Furthermore, the possible molecular mechanism for FaRCg1mediated resistance was constructed from comparative transcriptome analysis between resistant and susceptible cultivars. The subgenome-specific markers developed from the FaRCg1 candidate genes could be effectively used to improve strawberry varieties for CCR resistance.

\section{MATERIALS AND METHODS}

\section{Plant Material and Inoculation}

Two cultivated strawberry varieties, 'Florida Elyana' (FaRCg1: heterozygous resistant) and 'Strawberry Festival' (farcg1: susceptible) were used for the comparative transcriptome data analysis. The strawberry runner plants were grown in the greenhouse for 6 weeks and kept in a growth room $\left(22^{\circ} \mathrm{C}\right.$, $16 \mathrm{~h}$ light at 300 lux) until the inoculation and sample collections for RNA-seq. The field isolate 97-15A of C. gloeosporioides was used for the inoculation. This isolate was originally collected from the infected crown tissue of 'Sweet Charlie' in the field 
(MacKenzie et al., 2006). The isolate was cultured on PotatoDextrose Agar (PDA) media for 10 days at $24^{\circ} \mathrm{C}$, and then spores were harvested with sterile distilled water for inoculation $\left(1 \times 10^{5}\right.$ conidia/ml). Each plant of 'Florida Elyana' and 'Strawberry Festival' grown in 4 -in pots were inoculated with $2 \mathrm{ml}$ of the spore suspension and placed under a plastic dome after inoculation in a growth room $\left(23^{\circ} \mathrm{C}, 10 \mathrm{~h}\right.$ light, $14 \mathrm{~h}$ dark). Three biological replicates (10 plants for each replicate) were performed for the experiment.

\section{RNA Extraction and Sequencing}

For the extraction of RNA, plant roots were washed with distilled water twice and crown tissues were harvested at $72 \mathrm{~h}$ post inoculation (hpi). The tissue was ground under liquid nitrogen with a mortar and pestle. RNA extraction was conducted using Spectrum ${ }^{\mathrm{TM}}$ Plant Total RNA Kit following the manufacturer's protocol (Sigma-Aldrich, St. Louis, MO). The RNA concentration and quality were determined by Qubit 4 Fluorometer (Thermo Fisher Scientific, Waltham, United States). Samples with RNA integrity number (RIN) values greater than 7 were used for RNA sequencing. The RNA sequencing libraries were prepared with NEBNext ${ }^{\circledR}$ Ultra RNA Library Prep Kit for Illumina ${ }^{\circledR}$ (New England BioLabs, Boston, MA) using the standard manufacturer's protocol. The mRNA was sequenced using HiSeq 4000 sequencer with $2 \times 150 \mathrm{bp}$ paired-end sequences (Novogene, San Diego, CA).

\section{RNA Sequencing Data Analysis}

After Illumina sequencing, a total of 12 cDNA libraries (0 and $72 \mathrm{hpi}$ ) were available from two octoploid $F \times$ ananassa accessions 'Florida Elyana' (resistant) and 'Strawberry Festival' (susceptible). The $12 \mathrm{cDNA}$ libraries comprised of three replicates each for 'Florida Elyana' and 'Strawberry Festival' that were either water treated, or pathogen inoculated (PI). Sequencing results from each library were analyzed by FASTQC $0.11 .4^{1}$ to assess read quality. Trimming and adapter removal was performed using CLC Genomics Workbench 11.0. ${ }^{2}$ The parameters for trimming and adapter removal were performed by eliminating poor quality reads and ambiguous nucleotide sequences. The transcriptome data of C. gloeosporioides was obtained from Ensembl Fungi ${ }^{3}$ for filtering the fungal transcripts from the RNA-seq data. The trimmed short reads were mapped to the coding region sequence (CDS) of C. gloeosporioides, and all the unmapped reads were mapped to the full CDS of the octoploid strawberry reference genome (Edger et al., 2019) using CLC Genomics Workbench 11.0. ${ }^{4}$ It was difficult to differentiate the sequences between subgenomes, therefore, stringent mapping parameters were adopted with a length fraction of 0.8 , similarity fraction of 0.9 , insertion cost $=3$, deletion $\operatorname{cost}=3$, and mismatch cost $=2$. Reads mapped at multiple locations, that were ambiguous, or not mapped to any location were discarded for further downstream analysis.

\footnotetext{
${ }^{1}$ https://www.bioinformatics.babraham.ac.uk/projects/fastqc/ ${ }^{2}$ https://www.qiagenbioinformatics.com/

${ }^{3} \mathrm{http}$ ://fungi.ensembl.org/Colletotrichum_gloeosporioides/Info/Index? db=core

${ }^{4}$ https://digitalinsights.qiagen.com
}

The normalization of gene expression data was performed by computing the Reads Per Million mapped reads (RPKM; Mortazavi et al., 2008). Original expression values were transformed by adding a constant, as well as normalized by a scaling method (Bolstad et al., 2003). For the statistical analysis of differential gene expressions, test of Baggerly et al. (2003) was used, which compares the proportions of count one group with another and is suitable for the groups having biological replicates. This statistical test relates the mean expression value between the PI and control (water) samples. Multiple testing correction was employed by using Bonferroni corrected and FDR p-value correction (Dudoit et al., 2003). The CDS was called differentially expressed if (a) the normalized fold change was $\geq 2$-fold or (b) the difference in normalized value was $\geq 10$. Pairwise evaluations between the RNA-seq samples of: Elyana-water control (W) vs. Elyana-Pathogen Inoculated (PI), Festival-W vs. Festival-PI, and Festival-PI vs. Elyana-PI were performed. For MapMan analysis, all fasta files were generated and sent through the Mercator webtool ${ }^{5}$ for Bincode mapping. All differentially expressed with a fold change of $\geq 1.5$-fold in 'Florida Elyana' and 'Strawberry Festival' were sent to MapMan (Thimm et al., 2004) to classify affected metabolic pathways.

\section{Functional Annotation of Genes Differentially Expressed in Response to C. gloeosporioides}

Annotation of the DEGs was performed by the blastx program available in the BLAST+ package (Camacho et al., 2009). The sequences were annotated with an E-value cut-off of 1e-5 against non-redundant protein database available at NCBI and Ensembl Plants. ${ }^{6}$ The highest high-scoring segment pairs (HSP) were retrieved from corresponding database. To find the functions associated with differentially expressed genes from this study, a homology search against non-redundant (nr) protein database was performed at NCBI. ${ }^{7}$ In addition, set enrichment analysis was performed using the singular enrichment analysis tool from AgriGO (Du et al., 2010). The REViGO (Supek et al., 2011) was used to summarize the list of gene ontology (GO) terms by eliminating the redundant GO terms, and enrichment visualization of the gene sets was performed using Parametric Gene Set Enrichment Analysis (PGSEA; Kim and Volsky, 2005). To identify candidate genes associated with the resistance to CCR, the expression patterns for all annotated genes located in the genomic region of FaRCg1 were examined. The locations of candidate genes were placed accordingly on the physical map, constructed based on the octoploid reference genome. A multistep process was implemented to find candidate genes responsible for resistance against $C$. gloeosporioides. The criteria for selecting the candidate genes were as follows: (i) the candidate genes fall within the FaRCg1 genomic region, (ii) RNA-Seq expression of that particular gene should be higher in 'Florida

\footnotetext{
${ }^{5}$ https://mapman.gabipd.org/web/guest/app/mercator

${ }^{6}$ https://plants.ensembl.org/Arabidopsis_thaliana/Info/Index

${ }^{7}$ https://www.ncbi.nlm.nih.gov/refseq/about/nonredundantproteins/
} 
Elyana' (pathogen inoculation) as compared to 'Strawberry Festival' (pathogen inoculation), (iii) putative candidate genes were screened for sequence polymorphisms between resistant and susceptible haplotypes, and (iv) literature survey of previous reports to know if the biological function of a gene is related to resistance against fungal pathogens.

\section{Gene Expression Profiling of Candidate Genes for FaRCg1}

To validate the expression of candidate genes associated with FaRCg1 against C. gloeosporioides, sub-genome specific primers were designed for five candidate genes located in the FaRCg1 region: receptor-like protein kinase, $\mathrm{ABC}$ transporter, subtilisinlike protease, von Willebrand factor A domain-containing protein, and TIFY 11A-like. Primers were designed using IDT's PrimerQuest tool. ${ }^{8}$ For the quantitative reverse transcription PCR (qRT-PCR) assay, the Glyceraldehyde 3-phosphate dehydrogenase (GAPDH) gene was used as an internal control. The primer sequences used for this experiment are listed in Supplementary Table S1. About $1 \mu \mathrm{g}$ of total RNA extracted from crown tissues (water control and C. gloeosporioides infected at $0,42,72$, and $96 \mathrm{hpi}$ ) was converted to cDNA using Transcriptor First Strand cDNA synthesis kit (Roche, Switzerland) following the manufacturer's protocol. The qRT-PCR experiment was performed with the LightCycler ${ }^{\circledR} 480$ II system (Roche, Switzerland) using Forget-Me-Not ${ }^{\mathrm{TM}}$ EvaGreen ${ }^{\circledR}$ qPCR Master Mix (Biotium, Hayward, United States). The qRT-PCR reaction was performed in triplicate with $100 \mathrm{ng}$ of cDNA, $0.4 \mu \mathrm{l}$ of each primer $(400 \mathrm{nmol})$, and $3 \mu \mathrm{l}$ of EvaGreen ${ }^{\circledR}$ master mix for a final volume of $5 \mu \mathrm{l}$. The PCR conditions were as follows: $95^{\circ} \mathrm{C}$ for $5 \mathrm{~min}$ of an initial denaturation, followed by 40 cycles of $95^{\circ} \mathrm{C}$ for $20 \mathrm{~s}, 60^{\circ} \mathrm{C}$ for $20 \mathrm{~s}$, and $72^{\circ} \mathrm{C}$ for $20 \mathrm{~s}$. The melting curve analysis was performed via LightCycler ${ }^{\circledR} 480$ software to confirm that each amplicon had a single product. Cqs were calculated by the second derivative method on LightCycler ${ }^{\circledR}$ 480 software. Relative fold difference was analyzed by using the $2^{-\Delta \Delta C t}$ method (Paolacci et al., 2009). Statistical significance of qRT-PCR was analyzed by Duncan's multiple range test using the $\mathrm{R}$ software version 3.3.1 and $p$ values less than 0.05 were considered statistically significant.

\section{Development and Validation of Subgenome-Specific Markers for Candidate Genes}

Sequence variations present in the candidate genes of the FaRCg1 genomic region were used to develop functional subgenome-specific markers. The RNA-Seq data of 'Florida Elyana' (resistant) and 'Strawberry Festival' (susceptible), as well as two other cultivars of whole genome Illumina reads, 'Winter Dawn' (resistant; NCBI SRX accession no. SRX651592) and 'Sweet Charlie' (susceptible; NCBI SRX accession no. SRX651582) were used for the comparative sequence analysis. The reads from RNA-Seq and whole genome Illumina reads were mapped to the octoploid reference genome (cv. Camarosa)

${ }^{8}$ https://www.idtdna.com/PrimerQuest/Home/Index to generate a separated consensus sequence using CLC Genomics Workbench 11.0 (Qiagen, Venlo, Netherlands). The FaRCg1 candidate gene regions were retrieved from the consensus sequence and aligned with the corresponding genes from the reference genome to find sequence polymorphisms. Further, subgenome-specific high-resolution melting (HRM) markers were developed from the sequence polymorphisms (SNP or InDel) between resistant and susceptible accessions. Two octoploid reference genomes from 'Camarosa' and 'Reikou'10 were used to determine the specificity of primer sequences for targeted candidate genes of FaCg1 in chromosome 6-3. All primers used for this assay are provided in Supplementary Table S2.

To test the association between HRM markers developed from $\mathrm{FaRCg} 1$ candidate genes and resistance, a diverse breeding panel of 169 accessions were phenotyped for CCR disease in the field (Balm, GCREC, Florida) between 2014 and 2019 (100 for 2014-2017 and 69 accessions for 2018-2019; Supplementary Table S3). Three clonal replicates of each breeding accession were planted in a randomized complete block design. Field inoculations and disease ratings were conducted according to the methods of Anciro et al. (2018). Area Under the Disease Progress Curve (AUDPC) was calculated for each cultivar and selection in each year. Based on comparisons with known resistant and susceptible checks, each individual was categorized as resistant, moderately resistant, or susceptible. Three new HRM markers developed from three $\mathrm{FaRCg} 1$ candidate genes, ABC-1A, TIFY-1A, and RLK-1A, were tested in the 169 UF breeding accessions (Supplementary Table S3) as well as 40 North Carolina State University breeding accessions (Supplementary Table S5; Table 1). Marker genotype data were compared to CCR phenotype categories to estimate the predictive capacity of the markers. In addition, each marker was tested separately for its effect on AUDPC via one-way ANOVA in $\mathrm{R}$ software to determine the phenotypic variability explained by each marker. These results were used to more precisely delimit the genomic region associated with FaRCg1.

To extract DNA, the modified CTAB method (Noh et al., 2017) was used and further diluted to $50 \mathrm{ng} / \mu \mathrm{l}$ for the HRM assay. The PCR was conducted in a total volume of $5 \mu \mathrm{l}$ using $0.25 \mu \mathrm{l}$ of $5 \mu \mathrm{M}$ from both the forward and reverse primers, $1 \mu \mathrm{l}$ of DNA (20 ng), $1 \mu \mathrm{l}$ of PCR grade water, $2.5 \mu \mathrm{l}$ of AccuStart ${ }^{\mathrm{TM}}$ II PCR ToughMix ${ }^{\circledR}$ (Quantabio, Massachusetts) Master Mix, and $0.25 \mu \mathrm{l}$ of LC Green Plus Dye (BioFire Defense, Utah). All the reactions were performed using 384-well PCR plates in the LightCycler ${ }^{\circledR} 480$ II system (Roche Diagnostics, Germany). The PCR conditions were as follows: 45 cycles consisting of denaturation at $94^{\circ} \mathrm{C}$ for $20 \mathrm{~s}$, annealing at $62^{\circ} \mathrm{C}$ for $20 \mathrm{~s}$, and extension at $72^{\circ} \mathrm{C}$ for $20 \mathrm{~s}$. Further, the amplicon was denatured at $94^{\circ} \mathrm{C}$ for $60 \mathrm{~s}$ and the temperature was decreased to $40^{\circ} \mathrm{C}$ for renaturation of DNA. The melting curve initiated at $65^{\circ} \mathrm{C}$ with a rise of $1{ }^{\circ} \mathrm{C} / \mathrm{s}$ with 25 acquisitions $/{ }^{\circ} \mathrm{C}$ until it reached $95^{\circ} \mathrm{C}$. Finally, the melting curve data was retrieved and examined using the Melt Gene Scanning and Curve Genotyping HRM

\footnotetext{
${ }^{9}$ https://www.rosaceae.org/species/fragaria/all

${ }^{10} \mathrm{http}: / /$ strawberry-garden.kazusa.or.jp/blast.html
} 
TABLE 1 | Colletotrichum crown rot (CCR) phenotype and three newly developed high-resolution melting (HRM) marker genotype data of 30 selected accessions

\begin{tabular}{|c|c|c|c|c|c|}
\hline Accession & Phenotype & $A B C-1 A$ & TIFY-1A & RLK-1A & Source \\
\hline Florida Elyana & Resistant & + & + & + & $\begin{array}{l}\text { University of } \\
\text { Florida }\end{array}$ \\
\hline $\begin{array}{l}\text { Florida } \\
\text { radiance }\end{array}$ & Resistant & + & + & + & $\begin{array}{l}\text { University of } \\
\text { Florida }\end{array}$ \\
\hline Winter dawn & Resistant & + & + & + & $\begin{array}{l}\text { University of } \\
\text { Florida }\end{array}$ \\
\hline Treasure & Resistant & + & + & + & $\begin{array}{l}\text { Florida } \\
\text { (private } \\
\text { breeder) }\end{array}$ \\
\hline $\begin{array}{l}\text { Florida } \\
\text { brilliance }\end{array}$ & Susceptible & - & - & - & $\begin{array}{l}\text { University of } \\
\text { Florida }\end{array}$ \\
\hline $\begin{array}{l}\text { Strawberry } \\
\text { festival }\end{array}$ & Susceptible & - & - & - & $\begin{array}{l}\text { University of } \\
\text { Florida }\end{array}$ \\
\hline Florida beauty & Susceptible & - & - & - & $\begin{array}{l}\text { University of } \\
\text { Florida }\end{array}$ \\
\hline WinterStarTM & Susceptible & - & - & - & $\begin{array}{l}\text { University of } \\
\text { Florida } \\
\text { U. of }\end{array}$ \\
\hline Camarosa & Susceptible & - & - & - & $\begin{array}{l}\text { California } \\
\text { Davis } \\
\text { U. of }\end{array}$ \\
\hline Monterey & Susceptible & - & - & - & $\begin{array}{l}\text { California } \\
\text { Davis } \\
\text { U. of }\end{array}$ \\
\hline Fronteras & Susceptible & - & - & - & $\begin{array}{l}\text { California } \\
\text { Davis }\end{array}$ \\
\hline $\mathrm{NCH} 11-309$ & Resistant & + & + & + & $\begin{array}{l}\text { NC State } \\
\text { University }\end{array}$ \\
\hline NCK 12-191B & Resistant & + & - & - & $\begin{array}{l}\text { NC State } \\
\text { University }\end{array}$ \\
\hline NCS 11-002 & Resistant & - & - & - & $\begin{array}{l}\text { NC State } \\
\text { University }\end{array}$ \\
\hline NCK 12-181A & Resistant & - & - & - & $\begin{array}{l}\text { NC State } \\
\text { University }\end{array}$ \\
\hline NCS 10-080 & Resistant & - & - & - & $\begin{array}{l}\text { NC State } \\
\text { University }\end{array}$ \\
\hline NCS 10-147 & Resistant & - & - & - & $\begin{array}{l}\text { NC State } \\
\text { University }\end{array}$ \\
\hline NCK 12-194S & $\begin{array}{l}\text { Moderate } \\
\text { resistant }\end{array}$ & + & - & - & $\begin{array}{l}\text { NC State } \\
\text { University }\end{array}$ \\
\hline NCK 12-199D & $\begin{array}{l}\text { Moderate } \\
\text { resistant }\end{array}$ & - & - & - & $\begin{array}{l}\text { NC State } \\
\text { University }\end{array}$ \\
\hline NCK 12-186C & Susceptible & - & - & - & $\begin{array}{l}\text { NC State } \\
\text { University }\end{array}$ \\
\hline NCS 11-036 & Susceptible & - & - & - & $\begin{array}{l}\text { NC State } \\
\text { University }\end{array}$ \\
\hline NCS 11-057 & Susceptible & - & - & - & $\begin{array}{l}\text { NC State } \\
\text { University }\end{array}$ \\
\hline NCS 11-101 & Susceptible & - & - & - & $\begin{array}{l}\text { NC State } \\
\text { University }\end{array}$ \\
\hline NCS 11-117 & Susceptible & - & - & - & $\begin{array}{l}\text { NC State } \\
\text { University }\end{array}$ \\
\hline NCS 10-136 & Susceptible & - & - & - & $\begin{array}{l}\text { NC State } \\
\text { University }\end{array}$ \\
\hline Liz & Susceptible & - & - & - & $\begin{array}{l}\text { NC State } \\
\text { University }\end{array}$ \\
\hline
\end{tabular}

+, resistant HRM pattern; -, susceptible HRM pattern.

software of Roche LightCycler ${ }^{\circledR} 480$ II. The interpretation of the data was based on melting temperature and shape of the melting curves.

\section{RESULTS}

\section{Transcriptome Analysis and Differentially Expressed Genes in Response to C. gloeosporioides Infection}

To investigate transcriptome profiles of the FaRCg1-mediated resistance against C. gloeosporioides, RNA-Seq was conducted from two octoploid strawberry cultivars, 'Florida Elyana' (resistant, FaRCg1) and 'Strawberry Festival' (susceptible, farcg1). A total of 1,070 million reads were generated of which $99.8 \%$ passed the Illumina quality filter. All reads from the sequencing libraries, 'Strawberry Festival' pathogen inoculated (Festival-PI) and 'Florida Elyana' pathogen inoculated (Elyana-PI), were first mapped to the coding sequences of $C$. gloeosporioides ${ }^{11}$ to eliminate any pathogen related short reads. All other unmapped reads were further used to map to the octoploid strawberry reference genome, cv. Camarosa (Edger et al., 2019). Sequence reads associated with C. gloeosporiodes were only found in the samples of 'Florida Elyana' and 'Strawberry Festival' infected with the pathogen, indicating that the pathogen inoculation was successfully achieved in both cultivars and that the controls were not infected. A total of $89.5 \%$ of Festival-PI and $90.3 \%$ sequence reads of Elyana-PI were mapped to the full coding sequences of the octoploid strawberry reference genome (Table 2).

To identify DEGs after infection of C. gloeosporioides, the number of sequence reads was compared between the resistant and susceptible RNA-seq datasets. A total of 2,212 genes were differentially expressed in the resistant cultivar, 'Florida Elyana, after the pathogen infection (Figure 1A; Supplementary File 1). Among the DEGs, 1,311 genes were upregulated and 901 were downregulated. In the susceptible cultivar 'Strawberry Festival', 8,493 genes were differentially expressed after pathogen infection, 3,361 were upregulated and 5,132 were downregulated (Figure 1A; Supplementary File 2). A total of 10,857 DEGs were identified in the comparison of resistant and susceptible varieties against C. gloeosporioides. The 6,099 DEGs, which were upregulated were found to be associated with CCR resistance (Figure 1A; Supplementary File 3). The heatmap at the whole-genome level of DEGs showed the significant patterns of gene expressions between Elyana-PI and Festival-PI (Figure 1B). The hierarchical clustering shows two different groupings of differentially expressed genes in response to the pathogen infection in Elyana-PI and Festival-PI. This finding indicates that there is a specific group of genes expressed in Elyana-PI for the defense pathway of CCR resistance. The Venn diagram showed several groups of DEGs were common in the different comparisons: 854 DEGs for Elyana-PI vs. Festival-PI and Elyana-PI vs. Elyana-W, 1,220 DEGs for Festival-PI vs. Festival-W and Elyana-PI vs. Elyana-W, and 3,398 DEGs for Elyana-PI vs. Festival-PI and Festival-PI vs. Festival-W (Figure 1C). The total of 422 DEGs were common in all comparisons. The large number of genes related to plant defense responses were highly upregulated in the resistant accession 'Florida Elyana' compared to the susceptible accession 'Strawberry

\footnotetext{
${ }^{11}$ https://fungi.ensembl.org/Colletotrichum_gloeosporioides_cg_14_ gca_000446055/Info/Index
} 
TABLE 2 | Summary of the transcriptome sequencing dataset from 'Strawberry Festival' and 'Florida Elyana' after the infection of Colletotrichum gloeosporiodes.

\begin{tabular}{|c|c|c|c|c|c|}
\hline & Festival-W* & Festival-PI & Elyana-W & Elyana-PI & Total \\
\hline Raw read & $254,850,102$ & $274,301,732$ & $278,045,094$ & $263,158,878$ & $1,070,355,806$ \\
\hline High quality reads & $254,310,857$ & $274,069,821$ & $277,862,155$ & $263,021,234$ & $1,069,264,067$ \\
\hline $\begin{array}{l}\text { Reads mapped to } \\
\text { C. gloeosporioides }\end{array}$ & - & 2,372,726 (0.87\%) & - & 1,627,614 (0.62\%) & $4,000,340$ \\
\hline $\begin{array}{l}\text { Reads mapped to } F . \times \\
\text { ananassa (Cv. Camarosa) }\end{array}$ & $228,289,810$ (89.7\%) & $243,176,343$ (89.5\%) & $249,357,437$ (89.7\%) & 236,193,698 (90.3\%) & $957,017,288$ \\
\hline
\end{tabular}

The data for each sample is from the sum of three replicates per condition. *W, water control; PI, pathogen inoculated.

Festival' (Supplementary Files 1-3). To elucidate the role of identified DEGs in biotic stress responses, MapMan analysis was used to determine the genes involved in plant-pathogen interactions. The DEGs involved in biotic stress including jasmonic acid (JA), beta glucanase, cell wall, redox state, and ethylene response factor (ERF) were identified in the 'Florida Elyana' in response to the pathogen (Figure 2). Ten out of 12 genes encoding for enzymes involved in the signaling pathway of cell wall modification were identified in 'Florida Elyana' inoculated with C. gloeosporioides. Eleven out of 14 genes classified as beta glucanase and five transcripts classified as ERF were highly expressed in the resistant accession, 'Florida Elyana' in response to the pathogen (Figure 2B).

\section{Gene Ontology and KEGG Pathway Analysis for the Defense Mechanism Against C. gloeosporioides}

To identify if the DEGs have any functional process related to plant defense responses against C. gloeosporioides, GO analysis was performed for all DEGs by PGSEA. The GO term comparison between Elyana-PI vs. Festival-PI revealed that the biological processes (BP) upregulated in Elyana-PI were gene silencing by RNA, regulation of protein complex assembly, DsRNA fragmentation, response to dsRNA, post-transcriptional gene silencing, negative regulation of translation, negative regulation of cellular amide metabolic process, and glycerolipid metabolic process (Figure 3A). In the molecular function category, important GO terms, which were overrepresented in Elyana-PI, when compared with Festival-PI, were: Ras GTPase binding, small GTPase binding, enzyme binding, and protein kinase binding genes (Supplementary Figure S1). Similarly, in the Cellular Component category, important upregulated GO processes in Elyana-PI were genes associated with cell cortex, cell cortex part, side of membrane, cytoplasmic vesicle part, and endosome part (Supplementary Figure S2). Furthermore, in KEGG pathways, the upregulated genes in Elyana-PI, compared to Festival-PI, were closely associated with glycerolipid and nitrogen metabolisms (Figure 3B). The specific pathways upregulated in response to $C$. gloeosporioides were metabolic pathways, biosynthesis of secondary metabolites, biosynthesis of amino acids, ribosomes, protein processing in endoplasmic reticulum, carbon metabolism, and mRNA surveillance pathways. Several genes related to plant defense signaling pathway were highly induced in Elyana-PI, when compared with Festival-PI, such as syntaxin, 1-aminocyclopropane-1-carboxylate oxidase homolog 1-like, FK506-binding protein 4-like, receptor-like protein 12, probable CCR4-associated factor 1 homolog 11 , and probable WRKY transcription factor (Supplementary File 1).

\section{Identification of Candidate Genes for the FaRCg1-Mediated Resistance}

To identify candidate genes associated with the FaRCg1 resistance, the expression patterns of genes located within the FaRCg1 region were examined. A total of 38 genes in the FaRCg1 genomic region $(1.1 \mathrm{Mb})$ were differentially expressed in the resistant cultivar in response to the pathogen infection (Figure 4; Supplementary File 3). Among them, four genes were highly upregulated against C. gloeosporioides in the resistant accession: von Willebrand factor A domain-containing protein (VWA; maker-Fvb6-3-snap-gene-110.42-mRNA-1), subtilisin-like protease (Subtilases; augustus_masked-Fvb6-3-processed-gene111.2-mRNA-1), growth-regulating factor 5-like (maker-Fvb63-augustus-gene-113.31-mRNA-1), and TIFY 11A-like (makerFvb6-3-snap-gene-109.40-mRNA-1). Interestingly, all these genes are located within the FaRCg1 region. Furthermore, there are two additional genes related to plant defense, including the $\mathrm{ABC}$ transporter B family member 19-like (ABCB19) and the putative receptor-like protein kinase (RLK1A) located in the FaRCg1 region. However, RNA-Seq and qRT-PCR results showed that the expressions of both genes were not substantially induced in response to the pathogen infection.

With the analysis of quantitative RT-PCR, the gene expression of three candidate genes - TIFY11A, Subtilases, and VWA were validated in two susceptible (FL 12.90-53 and 'Strawberry Festival') and three resistant ('Florida Elyana', FL10-129, and 'Winter Dawn') accessions following infection with C. gloeosporioides at 0,42,72, and 96hpi. After inoculation all three candidate genes were highly upregulated in all resistant accessions (Figure 5). The expression of TIFY 11A, Subtilases, and VWA were drastically induced in all resistant accessions at 42 and $72 \mathrm{hpi}$. The level of VWA expression was significantly higher in all resistant accessions, at $96 \mathrm{dpi}$. The gene expression results indicate the potential roles of these candidate genes with FaRCg1-mediated resistance against C. gloeosporioides.

\section{Development of Gene-Specific Markers for FaRCg1 and Validation in Diverse Breeding Accessions}

The FaRCg1 region was delimited to approximately $1.2 \mathrm{Mb}$ with nine SNP markers from the $35 \mathrm{~K}$ array on linkage group $6 \mathrm{~B}$ ('Camarosa' chromosome 6-3) as shown in Figure 6 


\section{A}

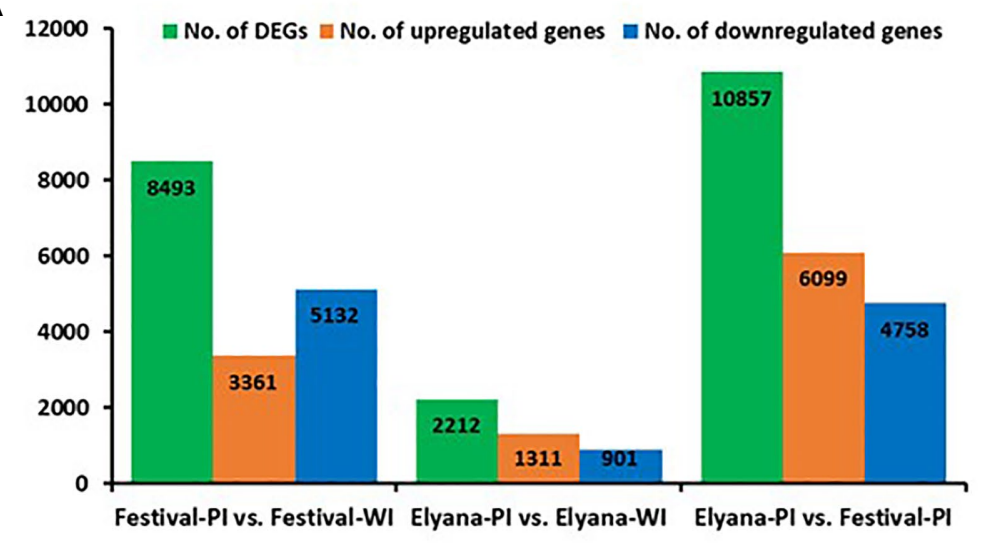

B

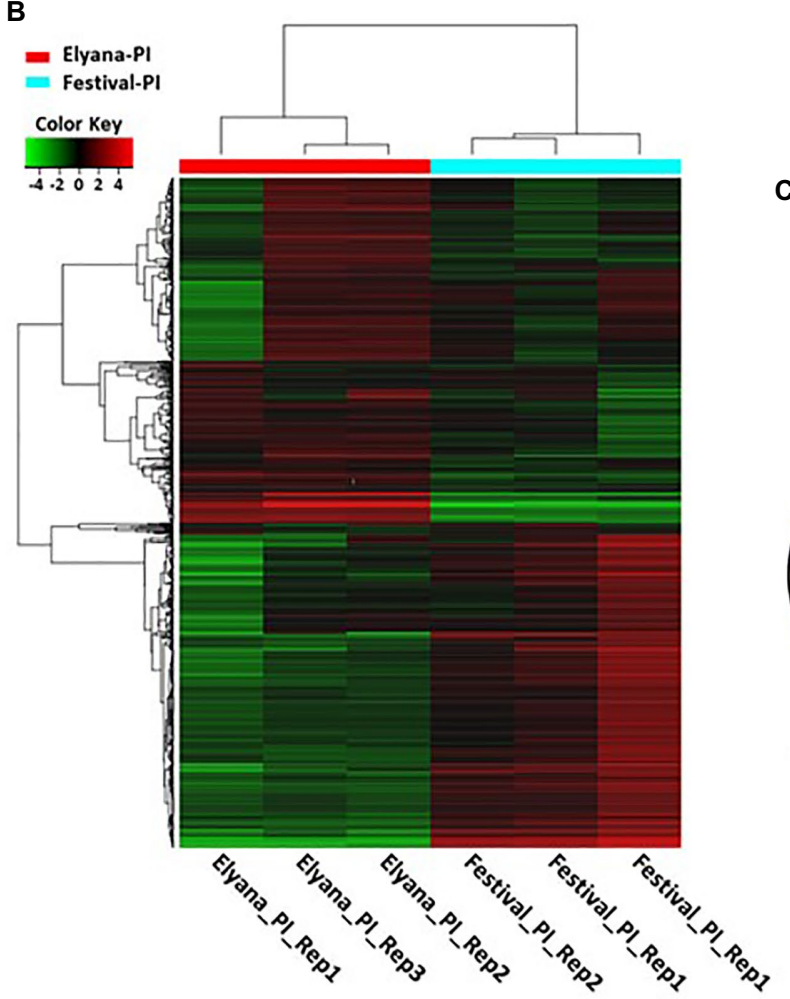

FIGURE 1 | (A) Histogram representing the number of differentially expressed genes (DEGs) detected on pairwise comparison between libraries. (B) Hierarchical clustering of genome-wide differentially expressed genes in response C. gloeosporioides. (C) Venn diagram depiction among Elyana-PI vs. Festival-PI, Elyana-Water vs. Elyana-PI and Festival-Water vs. Festival-PI.

(Anciro et al., 2018). According to our previous study, the two markers AX-89906235 (Fvb6-3: 10,796,874bp) and AX-89797117 (Fvb6-3: 11,326,278bp) were closely linked to FaRCg1-mediated resistance. However, the marker gap of about $500 \mathrm{~kb}$ was limiting. From this study, all candidate genes identified from transcriptome data analysis are located within the previously-identified FaRCg1 genomic region. To further fine-map and validate this region, subgenome-specific HRM

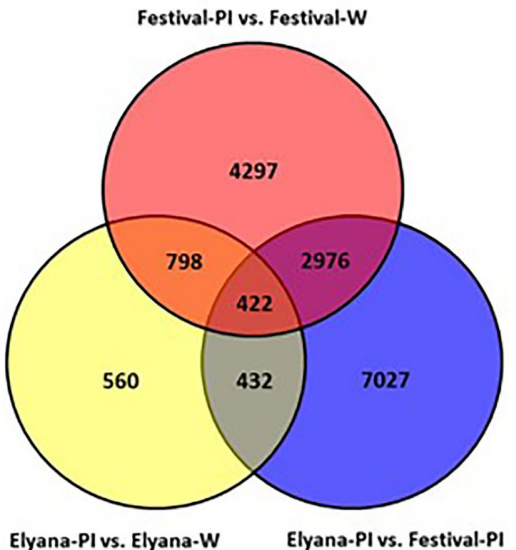

Elyana-PI vs. Elyana-W markers were designed using RNA and genomic DNA sequences (Illumina short reads) of five candidate genes - $A B C B 19$, TIFY11A, Subtilases, VWA, and RLK1A - between resistant ('Florida Elyana' and 'Winter Dawn') and susceptible (Sweet Sensation ${ }^{\circledR}$ 'Florida127' and 'Camarosa') accessions. The sequence polymorphisms present in resistant accessions were used for designing gene-specific functional markers (Figure 7A). Only three HRM markers developed from ABCB19, TIFY11A, and 


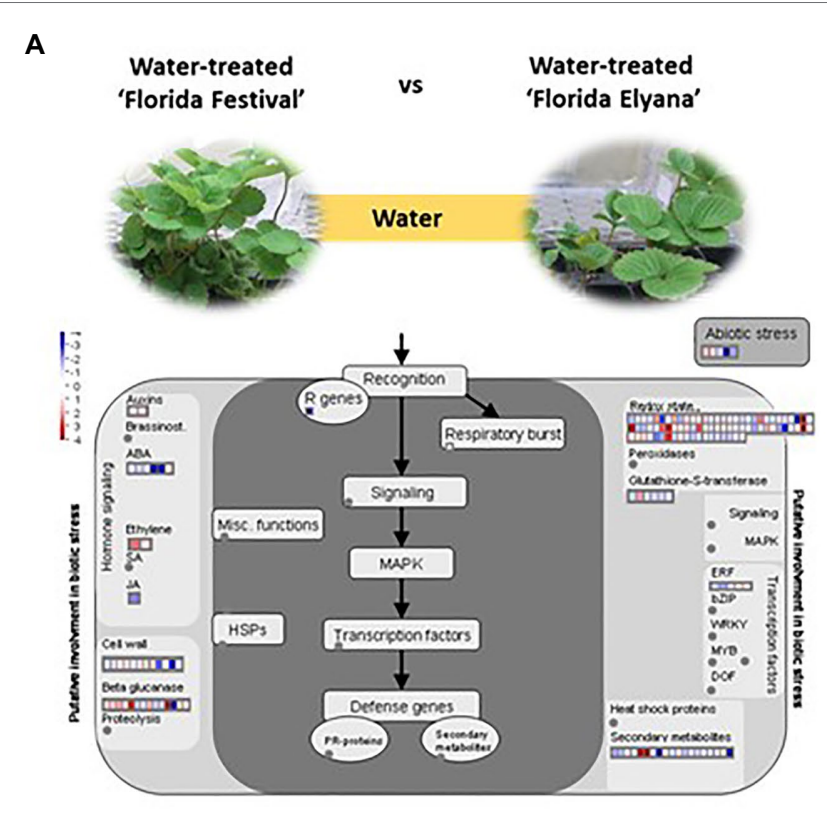

B

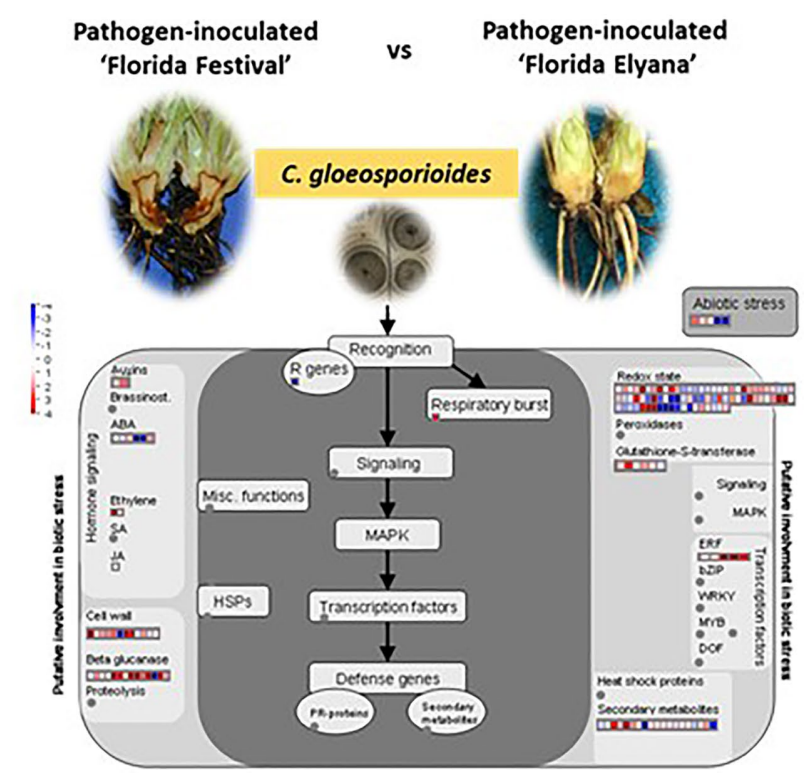

FIGURE 2 | MapMan visualization of DEGs related to different signaling and metabolic pathways under (A) water treatment and (B) pathogen inoculation between 'Florida Festival' and 'Florida Elyana.' The log2 fold changes of significant DEGs were imported and visualized in MapMan software (3.5.1 R2).

RLK1A showed distinct patterns of melting curves differentiating resistant and susceptible accessions (Figure 7A; Table 1). The three HRM markers - ABC-1A, TIFY-1A, and RLK-1A - were further tested with the UF breeding germplasm to determine the selection accuracy of markers. All three marker genotypes were highly co-segregated with the CCR phenotype collected from the field (2014-2019; Figure 7C; Table 1; Supplementary Table S3). As shown in Figure 7, the single marker analysis indicated that the marker for each candidate

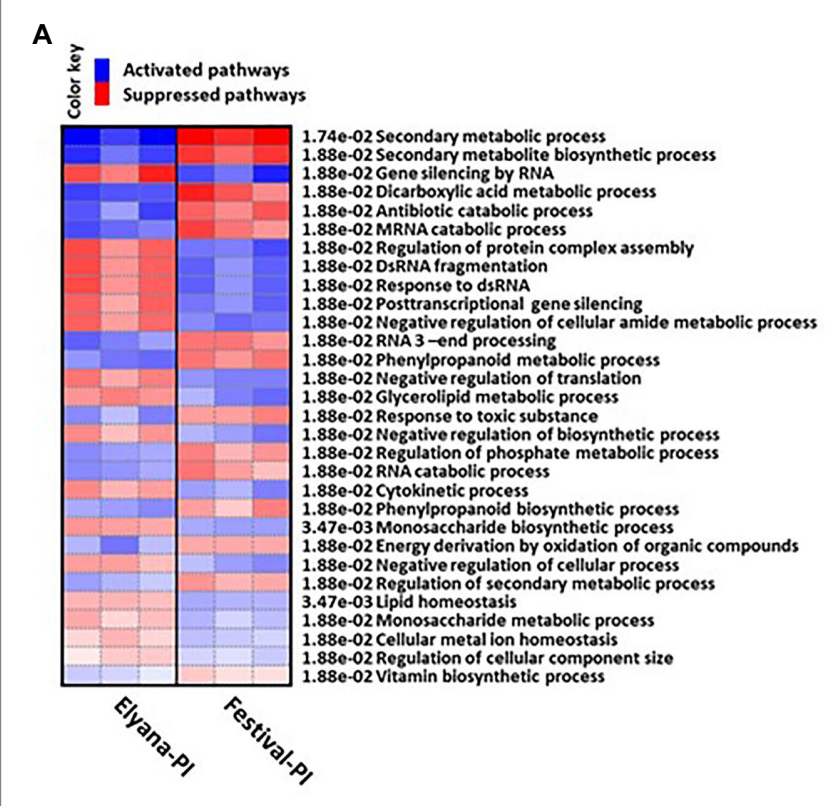

B

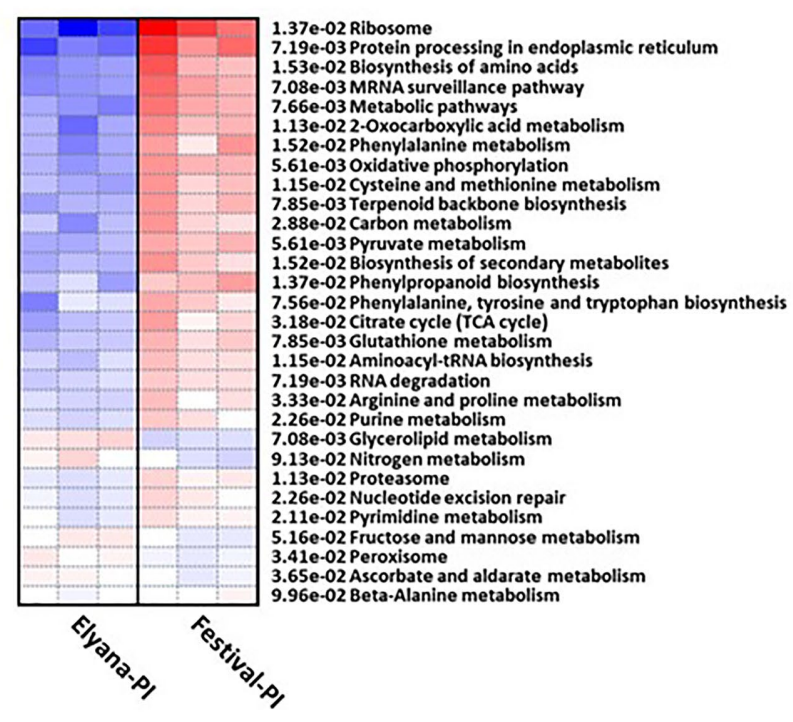

FIGURE 3 | Heatmap representation of the differentially expressed genes enriched gene ontology (GO) process under the category of (A) Biological Process (BP) and (B) KEGG pathways.

gene was highly associated with the FaRCg1-mediated resistance (Figure 7C; Table 1; Supplementary Tables S3 and S4). Among the three markers, the TIFY-1A marker showed the most distinct patterns of HRM curves between the resistant and susceptible accessions and further could be used for markerassisted selection.

These markers were also tested with breeding accessions from other public strawberry breeding programs in the United States (Table 1; Supplementary Table S5). Three cultivars from the University of California - 'Camarosa', 'Monterey', and 'Fronteras' - are susceptible to CCR, and all three markers were absent. Selections from North Carolina State University NCH 11-309, NCK 12-191B, NCS 11-002, NCK 12-181A, and 


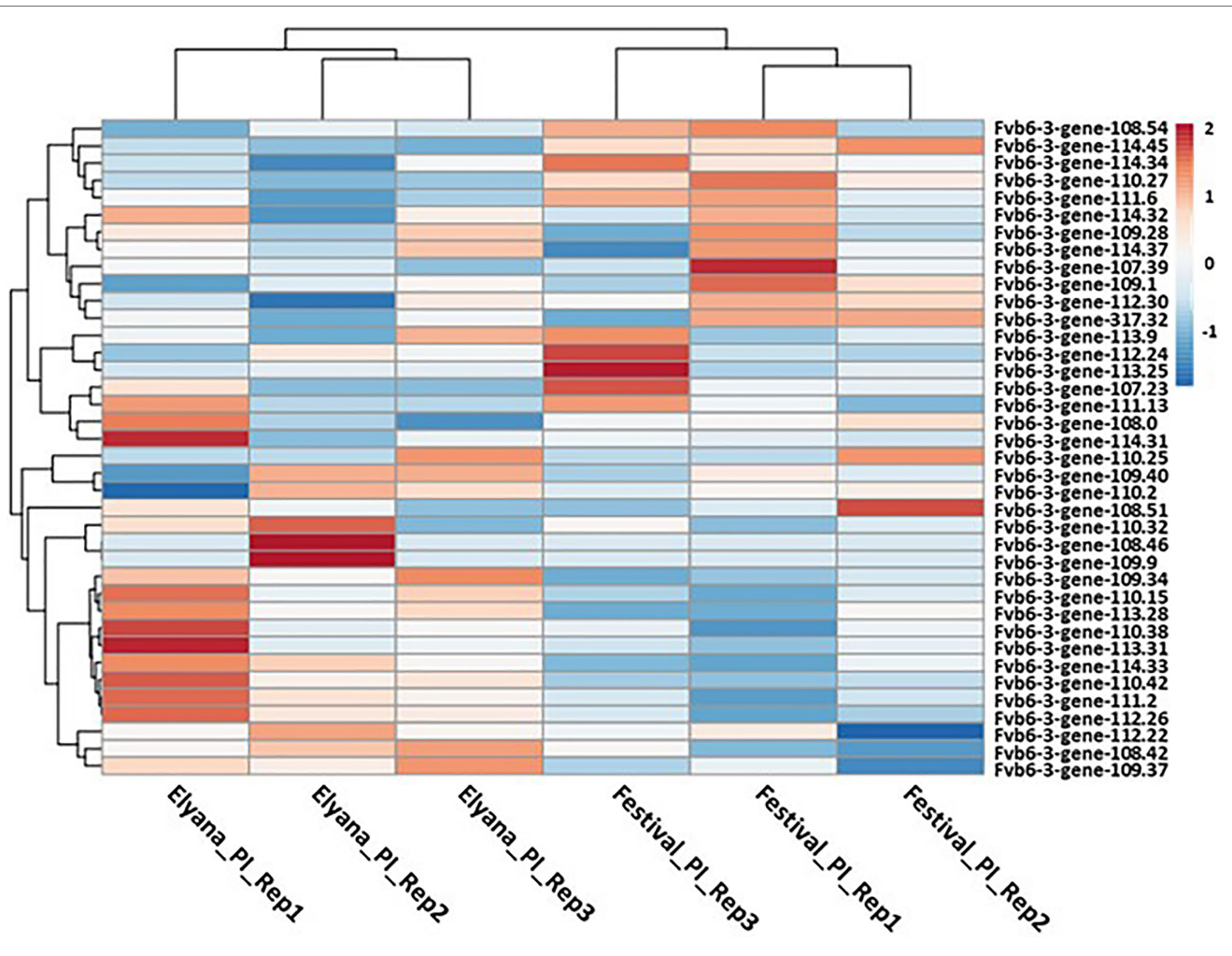

FIGURE 4 | Heatmap representation of the genes that lie within the FaRCg1 region. The normalized log2 transformed fold change of the expression value lying within the resistance locus due to C. gloeosporioides infection is indicated by a color scale comprising of brown (upregulated) and blue (downregulated). Each row represents a gene. A total of 38 genes were considered for this analysis.

NCK 12-194S - showed resistance to CCR in field conditions. All three markers are present in $\mathrm{NCH} 11-309$. Two resistant accessions - NCK 12-191B and NCK 12-194S - contain only the ABC-1A marker. Other resistant accessions - NCS 11-002, NCK 12-181A, NCS 10-147, and NCK 12-199D - did not contain all three markers, suggesting that the resistance might be not derived from FaRCg1, and suggesting the presence of other resistance source in the accessions.

\section{DISCUSSION}

Colletotrichum crown rot caused by C. gloeosporioides is one of the most common and destructive diseases in strawberry growing regions of the southeastern United States (Smith, 2008). Because most commercial cultivars are susceptible to CCR, development of new strawberry varieties with CCR resistance is critical for nursery and strawberry growers. In our previous study, a major locus FaRCg1 that accounts for most of the genetic variation for resistance against the necrotrophic phase C. gloeosporioides in UF breeding germplasm (Anciro et al., 2018). This locus was located in the linkage group 6B, but its physical location and genomic region were not fully characterized. In this study, the recently published octoploid reference genome was used to define FaRCg1 to the region $10.28-11.50 \mathrm{Mb}$ of the 'Camarosa' reference chromosome 6-3 (Figure 6). Furthermore, fine-mapping and identifying candidate genes at this locus could be a great avenue for the breeding of CCR resistance in cultivated strawberry.

Over the last 5 years, various DNA markers for disease resistance and fruit quality traits have been successfully developed in cultivated strawberry (Noh et al., 2017; Oh et al., 2020; Whitaker et al., 2020). Previous transcriptome analysis in strawberry described that differentially expressed genes in response to CCR pathogens are closely related to plant defense pathways (Casado-Díaz et al., 2006; Guidarelli et al., 2011, 2014; Amil-Ruiz et al., 2016; Wang et al., 2017; Zhang et al., 2018). In these studies, the RNA-seq reads were aligned to the reference genome of diploid wild strawberry, F. vesca. As a result, diverged and homoeologous transcripts present in the octoploid strawberry were potentially missing in their transcriptome analytical data. In this study, RNA-Seq reads from 'Florida Elyana' (resistant; FaRCg1) and 'Strawberry Festival' (susceptible; Farcg1) were aligned to a chromosome-scale reference genome of the octoploid strawberry (cv. Camarosa; Edger et al., 2019). This resolved the potential genome misassemblies and deletions in transcriptome assemblies when $F$. vesca was used as the reference genome in previous studies. As shown in Table 2, the high number of short reads were subsequently mapped for both 'Florida Elyana' (89.7-90.3\%) and 'Florida Festival' (89.5-89.7\%). Approximately $10 \%$ of reads were not mapped to the reference genome. This is possibly due to the sequence variations from diverse genetic backgrounds among different cultivars. The reference genome 'Camarosa' 


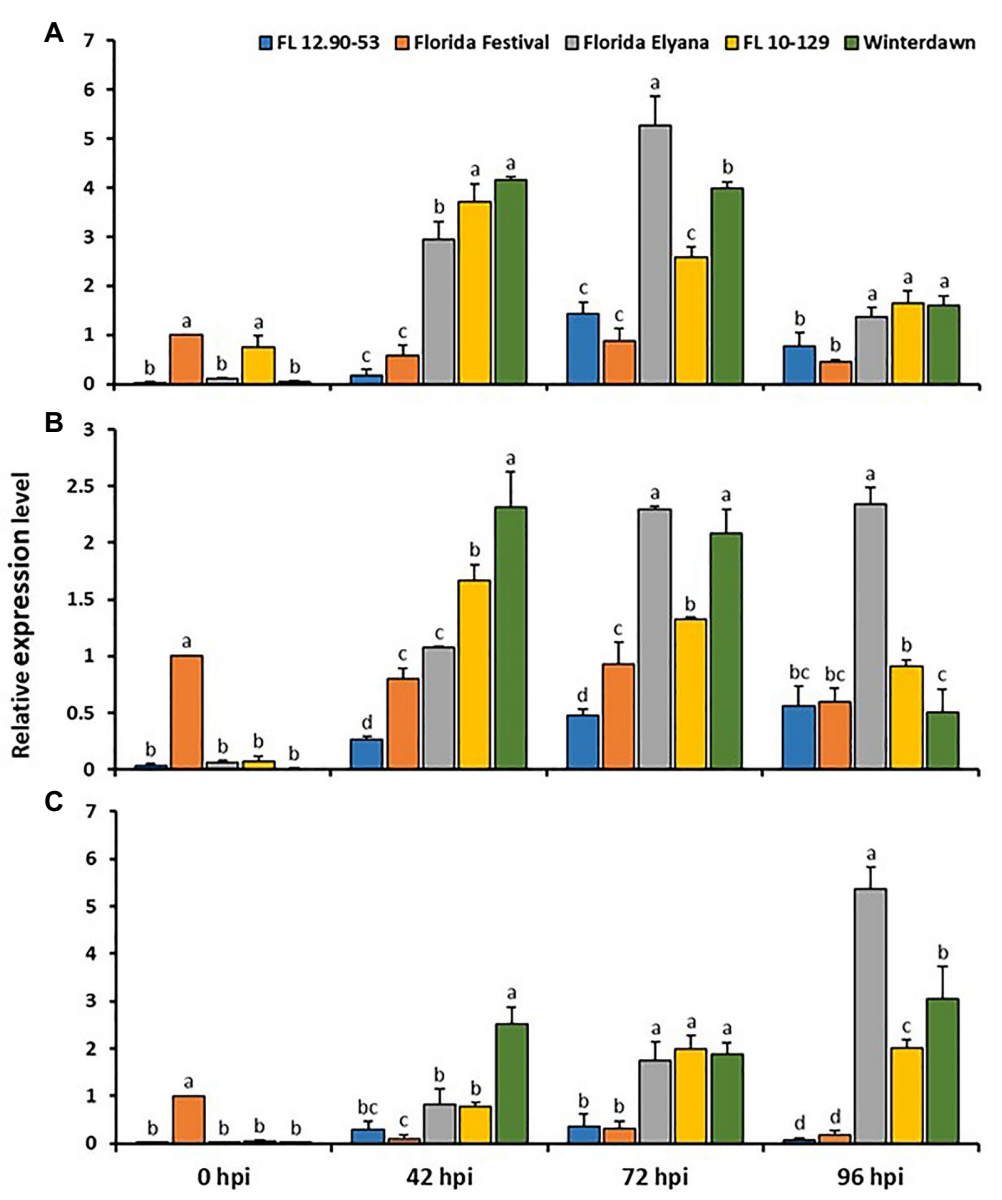

FIGURE 5 | The qRT-PCR experiment for the selected upregulated genes in the FaRCg1 region-based RNA-Seq analysis (A) TIFY 11A (B) Subtilisin-like protease, and (C) von Willebrand factor A domain containing protein. The crown tissues from all the resistant and susceptible accessions were used for both pathogeninoculated and water-inoculated at 0, 42, 72, and 96h post inoculation (hpi). Water-inoculated susceptible 'Strawberry Festival' at Ohpi was referred as calibrator. The accession FL 12.90-53 and 'Strawberry Festival' are susceptible to CCR, whereas FL 10-129, 'Winter Dawn' and 'Florida Elyana' are resistant to CCR. The calculation of relative quantification of genes was performed by $2^{-\Delta \Delta C t}$ method. Glyceraldehyde 3-phosphate dehydrogenase (GAPDH) was used as a housekeeping gene for normalization and the mean SD of data from three biological replicates was used for making the graph. Values with different letters are significantly different at $p<0.05$, as assessed using Duncan's multiple-range test. Error bars represent + SE of the means of three independent experiments.

does not have FaRCg1, and there is a possibility that RNA sequencing reads from 'Florida Elyana' and 'Florida Festival' could not mapped to the reference genome and be missing from our gene expression analysis. However, to develop the potential functional markers, we selected the most differentially expressed candidate genes (TIFY11A, Subtilases, and VWA) among resistant and susceptible accessions. All these marker genotypes were highly cosegregated with the phenotype of CCR. The genome assembly data containing FaRCg1 would be essential to understand the variation of genes and sequences in the resistance genomic region.

Analysis of the transcriptome could reveal potential molecular mechanisms of defense responses against C. gloeosporioides in cultivated strawberry. Transcripts related to gene silencing by RNA and the glycerolipid metabolic process were highly upregulated in the resistant cultivar 'Florida Elyana' in response to the pathogen (Elyana-PI). The biological process of gene silencing by RNA has been reported previously as an important defense mechanism in Morschella esculenta and Arabidopsis thaliana against Colletotrichum species (Pinweha et al., 2015; Soto-Suárez et al., 2017). Glycerolipid metabolic process has also been shown for defense responses against fungal pathogens in A. thaliana (Kachroo et al., 2004, 2005; Nandi et al., 2004; Chandra-Shekara et al., 2007). Glycerolipid metabolism was the most enriched pathway found in Elyana-PI from the analysis of the KEGG pathway. In the cellular component category, DEGs related to cell cortex were more represented in Elyana-PI compared to Festival-PI. The importance of the cortex for disease resistance against fungal pathogens has been reported in strawberry (Terry et al., 2004). The histopathological variation between resistant and susceptible strawberry plants after infection by Colletotrichum fragariae showed the deposition of pectic substance within the intercellular space of cortex and stiffening of the cell wall in resistant cultivars (Milholland, 1982). In the molecular function category, Ras GTPase binding, small GTPase binding, enzyme binding, and protein kinase binding 


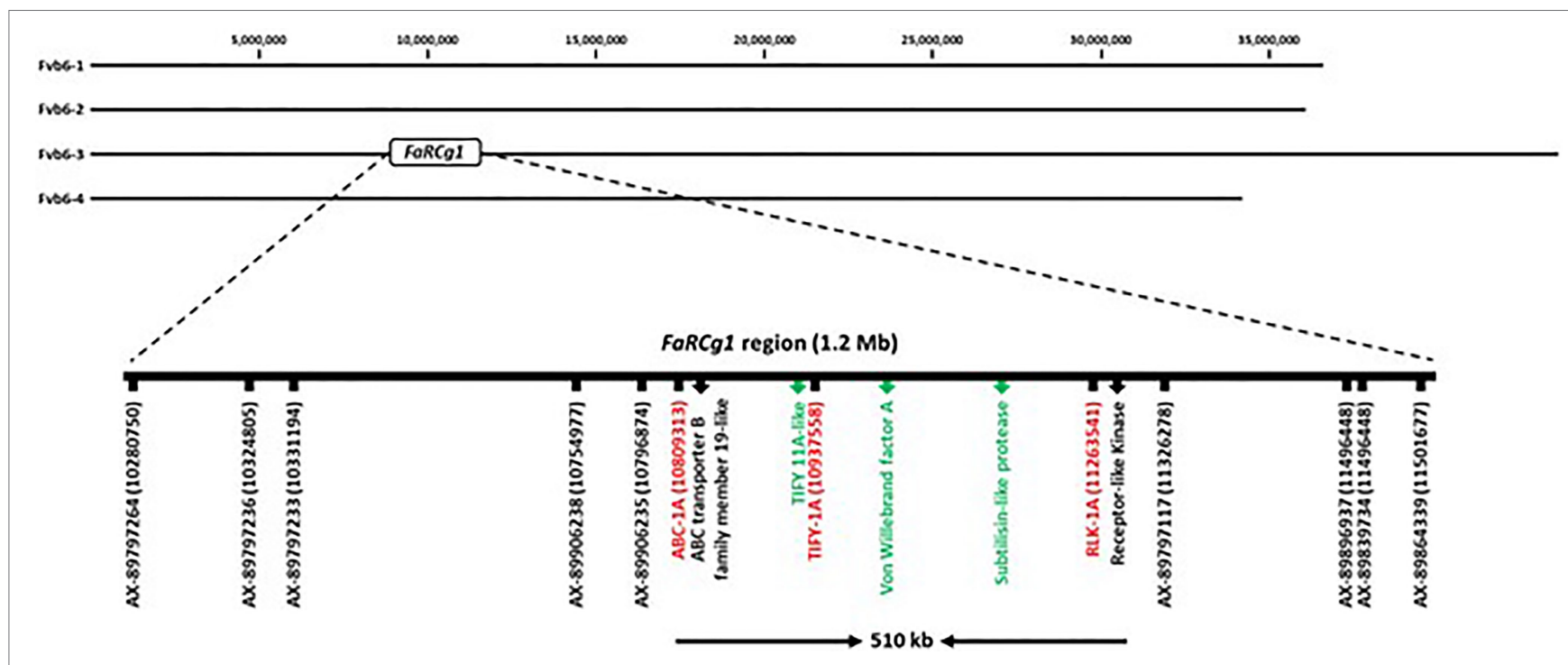

FIGURE 6 | Physical map of the FaRCg1 locus with genes upregulated in response to C. gloeosporioides highlighted in green, and the newly designed subgenome specific markers are represented in red.

A

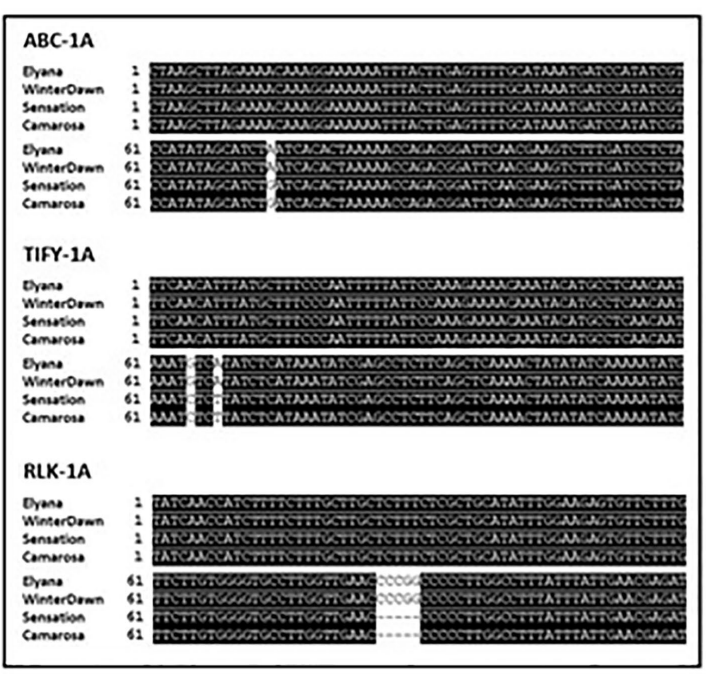

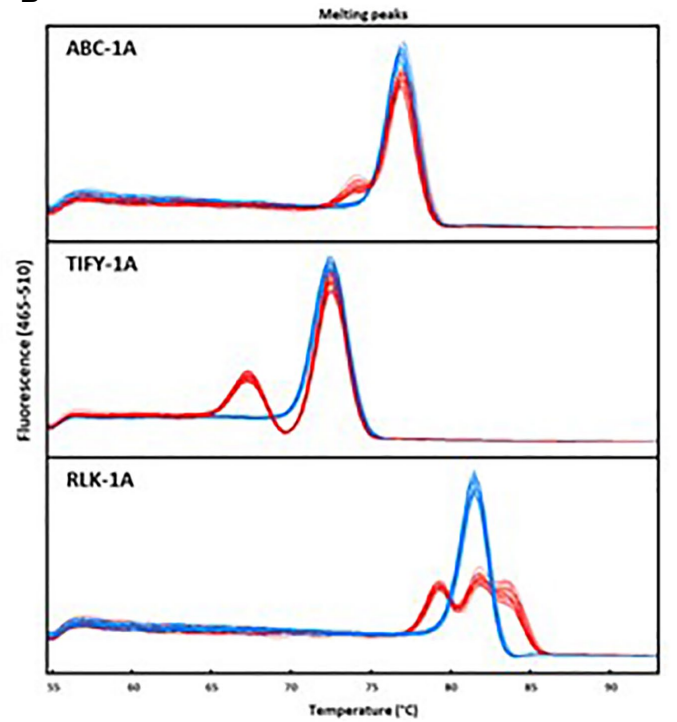

C
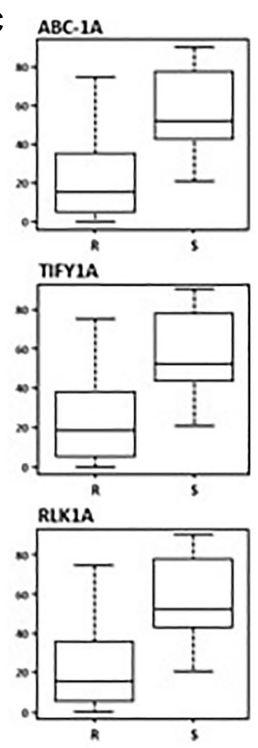

FIGURE 7 | Development of gene-specific HRM markers and validation with association mapping breeding panels. (A) Multiple sequence alignment view of polymorphism flanking region of ABC-1A, TIFY-1A, and RLK-1A. (B) High resolution melting curve patterns for ABC-1A, TIFY-1A, and RLK-1A testing with 169 accessions. The blue line shows the susceptible pattern and red line depicts the resistant pattern. (C) Boxplot analysis of area under disease progression curve (AUDPC) for genotyping of three markers ABC-1A, TIFY-1A, and RLK-1A.

genes were the mostly upregulated group in Elyana-PI as compared to Festival-PI. These genes are largely involved in the initiation of plant innate immunity through signal induction, translocation and transduction to recognize PAMs, and activate pathogen triggered immunity (PTI; Bhadauria et al., 2013). Furthermore, receptor tyrosine kinases (RTKs) such as receptorlike protein kinase, L-type lectin-domain containing receptor kinase, and wall associated receptor kinase were also highly upregulated against C. gloeosporioides in Elyana-PI. The main function of RTKs have been well characterized for the activation of various defense signaling transduction pathways by modulating the activities of transcript factors (Afzal et al., 2008; Singh and Zimmerli, 2013; Hurni et al., 2015). The most upregulated protein in Elyana-PI was Syntaxin, which has an important role in imparting penetration immunity against fungal pathogens (Zhang et al., 2007).

It was reported in the previous study that the two SNP markers, AX-89906235 (10.79 Mb) and AX-89907117 (11.32 Mb), 
were closely linked to the FaRCg1-mediated resistance (Anciro et al., 2018). However, as shown in Figure 6, the marker gap is about $510 \mathrm{~Kb}$, and a DNA marker was suitable markerassisted selection was not developed. There were five genes related to plant defense response in this genomic region. Our transcriptome data and gene expression results showed that TIFY11A, Subtilases, and VWA were substantially induced in response to the pathogen in resistance accessions, indicating potential candidate genes for the FaRCgl-mediated resistance against C. gloeosporioides. The TIFY transcription factor is plant specific gene and important for the proper development and modulation of defense responses (Bai et al., 2011; Xia et al., 2017). The TIFY transcription factor is connected to the JA signaling pathway. More recent evidence suggests that $\mathrm{JA}$ is involved in the induction of genes that act primarily in defense against necrotrophic and biotrophic fungal pathogens (Antico et al., 2012; Patkar and Naqvi, 2017; Zhang et al., 2017). The TIFY transcription factor inhibits the expression of JA receptive genes by cooperating with MYC2 and bHLH transcription factors when JA level is low. On the contrary, when JA level is augmented, the TIFY transcription factor could bind with LRR/F-box protein and cause degradation of TIFY repressors by $26 \mathrm{~S}$ proteasome that ultimately leads to the downregulation of primary response genes (Chung et al., 2008). A recent study showed that JA was found to be an important phytohormone in coffee plants against Colletotrichum kahawae (Diniz et al., 2017). The von Willebrand factor A (VWA) is an extensively dispersed protein that comprises domain for interactions between proteins (Whittaker and Hynes, 2002), and highly similar across diverse eukaryotes. In Arabidopsis, the Phytochrome and Flowering Time 1 (PFT1) protein encoding the VWA domain is required for basal resistance to necrotrophic fungal pathogen (Kidd et al., 2009). The subtilisin-like protease protein belongs to the class of serine proteases and has an important role in the development and initiation of signaling cascades. Subtilisin-like proteases are known for their participations in both biotic and abiotic stresses (Figueiredo et al., 2018). It has been first reported that subtilisin-like protease was involved in the resistance against citrus exocortis viroid in tomato (Granell et al., 1987). The foliar spray of subtilisin-like protease also imparts partial immunity in strawberry plants against hemibiotrophic Colletotrichum acutatum and necrotrophic Botrytis cinerea pathogens (Chalfoun et al., 2013). Colletotrichum gloeosporioides has two different infection phases; hemibiotrophic leaf infection and necrotrophic crown rot in strawberry plants (Jimenez, 2020). The mode of infection in hemibiotrophic phase combines an initial short biotrophic infection stage and later highly destructive necrotrophic development mostly in strawberry leaves. These two different infection phases occur sequentially. In highly susceptible cultivars, necrotic symptoms are often appeared days after inoculation, but the necrotic infection developed after leaf senescence on more tolerant cultivars (Jimenez, 2020). It is still unknown whether genes associated with the resistance to either hemibiotrophic (leaves) or necrotrophic (crown) phase are closely related. Our previous study reported that FaRCgl is the major locus conferring the resistance to crown rot in cultivated strawberry during the necrotrophic infection. However, it has not been determined yet if cultivars with FaRCgl would be resistant to the hemibiotrophic leaf infection in strawberry. In this study, we determined that early defense response genes associated with the FaRCg1-mediated resistance ( $72 \mathrm{hpi}$ ) in crown tissues against C. gloeosporioides, because RNA transcripts could be rapidly degraded during the later necrotic infection process. In the future study, it would be important to examine gene expression patterns during the hemibiotropic and later necrotrophic infection phases. The results could provide valuable information to understand the sophisticated genetic defense system in different phases of infections by C. gloeosporioides in strawberry. In this study, subgenome-specific functional HRM markers for FaRCg1 were newly developed and validated with cultivars and breeding accessions from UF, UCD, and NCSU. The HRM marker data was highly correlated with CR phenotype of UF breeding accessions and UCD cultivars (Supplementary Table 3). All three markers - ABC-1A, TIFY-1A, and RLK-1A - were tested in NCSU breeding accessions, showing resistance-associated marker alleles in the resistant accession, $\mathrm{NCH}$ 11-309, suggesting a possible association with FaRCg1. Moderately resistant accessions such as NCK 12-194S, and NCK 12-199D did not contain the resistant marker alleles. It is likely that moderate levels of CCR resistance are conferred by genes with small effects. The field data from NCSU showed that NCH 11-309 did not show CCR symptoms under stressful conditions, even when the field was flooded (Supplementary Figure S3; Jimenez, 2020). However, a medium resistant accession, NCK 12-199D, displayed late onset of symptoms under those same conditions (Supplementary Figure S3). Using the gene specific markers associated with FaRCg1, it was possible to confirm the presence or absence of FaRCg1 for outside breeding programs. The markers developed in this study were successfully used in UF and UCD accessions. It was found that some of FaRCg1 markers were not present in the resistant NCSU accessions, suggesting the presence of different resistance factors. According to NCSU genome-wide association study (GWAS) data, the resistance/tolerance in a mapping population was related to a QTL found on linkage group 5-3 (Jimenez, 2020) and was not related to the markers for FaRCg1 in LG 6-3 (Anciro et al., 2018). It is likely that the QTL on LG5-3 is conferring tolerance or resistance under low stress conditions in other resistant accessions. This finding suggests the possibility of a second QTL adding to crown rot resistance and the potential to pyramid both loci to achieve greater resistance.

In summary, the genomic region of $F a R C g 1$ was more finely mapped, and transcriptome data analysis revealed three candidate genes for CCR resistance in the octoploid cultivated strawberry: TIFY $11 \mathrm{~A}$, a subtilisin-like protease, and a von Willebrand factor A domain. Potentially causal sequence variations within the candidate genes were identified, and subgenome-specific markers were developed for marker-assisted breeding. Overall, our findings provide a valuable foundation for further studies of the possible molecular mechanisms involved in resistance against C. gloeosporioides in the octoploid cultivated strawberry. 


\section{DATA AVAILABILITY STATEMENT}

The datasets presented in this study can be found in online repositories. The names of the repository/repositories and accession number(s) can be found in the article/ Supplementary Material.

\section{AUTHOR CONTRIBUTIONS}

SL and SC conceived and designed the research. SC performed RAN sequencing data analysis, gene expression profiling, HRM marker development, and data analysis. YO performed gene expression data analysis, HRM marker analysis, and data analysis. $\mathrm{HH}$ performed MapMan analysis. NS, AA, VW, JC, GF, and SL conducted other experiments needed for this manuscript. SC, SL, YO, and $\mathrm{HH}$ wrote the manuscript. All authors contributed to the article and approved the submitted version.

\section{FUNDING}

This work was supported by the Florida Strawberry Growers Association and Specialty Crops Research Initiative grant no.

\section{REFERENCES}

Afzal, A. J., Wood, A. J., and Lightfoot, D. A. (2008). Plant receptor-like serine threonine kinases: roles in signaling and plant defense. Mol. Plant-Microbe Interact. 21, 507-517. doi: 10.1094/MPMI-21-5-0507

Amil-Ruiz, F., Garrido-Gala, J., Gadea, J., Blanco-Portales, R., Muñoz-Mérida, A., Trelles, O., et al. (2016). Partial activation of SA-and JA-defensive pathways in strawberry upon Colletotrichum acutatum interaction. Front. Plant Sci. 7:1036. doi: $10.3389 /$ fpls.2016.01036

Anciro, A., Mangandi, J., Verma, S., Peres, N., Whitaker, V. M., and Lee, S. (2018). FaRCg1: a quantitative trait locus conferring resistance to Colletotrichum crown rot caused by Colletotrichum gloeosporioides in octoploid strawberry. Theor. Appl. Genet. 131, 2167-2177. doi: 10.1007/s00122-018-3145-z

Antico, C. J., Colon, C., Banks, T., and Ramonell, K. M. (2012). Insights into the role of jasmonic acid-mediated defenses against necrotrophic and biotrophic fungal pathogens. Front. Biol. 7, 48-56. doi: 10.1007/s11515-011-1171-1

Baggerly, K. A., Deng, L., Morris, J. S., and Aldaz, C. M. (2003). Differential expression in SAGE: accounting for normal between-library variation. Bioinformatics 19, 1477-1483. doi: 10.1093/bioinformatics/btg173

Bai, Y., Meng, Y., Huang, D., Qi, Y., and Chen, M. (2011). Origin and evolutionary analysis of the plant-specific TIFY transcription factor family. Genomics 98, 128-136. doi: 10.1016/j.ygeno.2011.05.002

Barbey, C. R., Hogshead, M. H., Harrison, B., Schwartz, A. E., Verma, S., Oh, Y., et al. (2021). Genetic analysis of methyl anthranilate, mesifurane, linalool and other flavor compounds in cultivated strawberry (Fragariax ananassa). Front. Plant Sci. 12:615749. doi: 10.3389/fpls.2021.615749

Bassil, N. V., Davis, T. M., Zhang, H., Ficklin, S., Mittmann, M., Webster, T., et al. (2015). Development and preliminary evaluation of a $90 \mathrm{~K}$ axiom ${ }^{\circledR}$ SNP array for the allo-octoploid cultivated strawberry Fragariax ananassa. BMC Genomics 16:155. doi: 10.1186/s12864-015-1310-1

Bhadauria, V., Bett, K. E., Zhou, T., Vandenberg, A., Wei, Y., and Banniza, S. (2013). Identification of Lens culinaris defense genes responsive to the anthracnose pathogen Colletotrichum truncatum. BMC Genet. 14:31. doi: 10.1186/1471-2156-14-31

Bolstad, B. M., Irizarry, R. A., Åstrand, M., and Speed, T. P. (2003). A comparison of normalization methods for high density oligonucleotide array data based on variance and bias. Bioinformatics 19, 185-193. doi: 10.1093/bioinformatics/19.2.185
2017-51181-26833 from the USDA National Institute of Food and Agriculture.

\section{ACKNOWLEDGMENTS}

The authors acknowledge the strawberry breeding group at UF/IFAS Gulf Coast Research and Education Center for their technical supports throughout this study.

\section{SUPPLEMENTARY MATERIAL}

The Supplementary Material for this article can be found online at: https://www.frontiersin.org/articles/10.3389/fgene.2021.730444/ full\#supplementary-material

Supplementary Figure S1 | Heatmap representation of the differentially expressed genes enriched GO process under the category of molecular function.

Supplementary Figure S2 | Heatmap representation of the differentially expressed genes enriched GO process under the category of cellular component.

Supplementary Figure S3 | Resistance to C. gloeosporioides crown rot in $\mathrm{NCH}$ 11-309 (A,B) and early tolerance in NCK 12-199D (C,D) during late summer evaluations.

Camacho, C., Coulouris, G., Avagyan, V., Ma, N., Papadopoulos, J., Bealer, K. et al. (2009). BLAST+: architecture and applications. BMC Bioinformatics 10:421. doi: 10.1186/1471-2105-10-421

Casado-Díaz, A., Encinas-Villarejo, S., Santos, B. D. L., Schilirò, E., Yubero-Serrano, E. M., Amil-Ruíz, F., et al. (2006). Analysis of strawberry genes differentially expressed in response to Colletotrichum infection. Physiol. Plant. 128, 633-650. doi: 10.1111/j.1399-3054.2006.00798.x

Chalfoun, N. R., Grellet-Bournonville, C. F., Martínez-Zamora, M. G., Díaz-Perales, A., Castagnaro, A. P., and Díaz-Ricci, J. C. (2013). Purification and characterization of AsES protein: a subtilisin secreted by Acremonium strictum is a novel plant defense elicitor. J. Biol. Chem. 288, 14098-14113. doi: $10.1074 /$ jbc.M112.429423

Chandra-Shekara, A., Venugopal, S. C., Barman, S. R., Kachroo, A., and Kachroo, P. (2007). Plastidial fatty acid levels regulate resistance genedependent defense signaling in Arabidopsis. Proc. Natl. Acad. Sci. U. S. A. 104, 7277-7282. doi: 10.1073/pnas.0609259104

Chung, H. S., Koo, A. J., Gao, X., Jayanty, S., Thines, B., Jones, A. D., et al. (2008). Regulation and function of Arabidopsis JASMONATE ZIM-domain genes in response to wounding and herbivory. Plant Physiol. 146, 952-964. doi: $10.1104 /$ pp.107.115691

Diniz, I., Figueiredo, A., Loureiro, A., Batista, D., Azinheira, H., Várzea, V., et al. (2017). A first insight into the involvement of phytohormones pathways in coffee resistance and susceptibility to Colletotrichum kahawae. PLoS One 12:e0178159. doi: 10.1371/journal.pone.0178159

Du, Z., Zhou, X., Ling, Y., Zhang, Z., and Su, Z. (2010). agriGO: a GO analysis toolkit for the agricultural community. Nucleic Acids Res. 38, W64-W70. doi: $10.1093 /$ nar/gkq310

Dudoit, S., Shaffer, J. P., and Boldrick, J. C. (2003). Multiple hypothesis testing in microarray experiments. Stat. Sci. 18, 71-103. doi: 10.1214/ss/1056397487

Edger, P. P., Poorten, T. J., Vanburen, R., Hardigan, M. A., Colle, M., McKain, M. R., et al. (2019). Origin and evolution of the octoploid strawberry genome. Nat. Genet. 51, 541-547. doi: 10.1038/s41588-019-0356-4

Figueiredo, J., Sousa Silva, M., and Figueiredo, A. (2018). Subtilisin-like proteases in plant defence: the past, the present and beyond. Mol. Plant Pathol. 19, 1017-1028. doi: 10.1111/mpp.12567

Gao, L., Tu, Z. J., Millett, B. P., and Bradeen, J. M. (2013). Insights into organ-specific pathogen defense responses in plants: RNA-seq analysis of 
potato tuber-Phytophthora infestans interactions. BMC Genomics 14:340. doi: 10.1186/1471-2164-14-340

Granell, A., Belles, J., and Conejero, V. (1987). Induction of pathogenesis-related proteins in tomato by citrus exocortis viroid, silver ion and ethephon. Physiol. Mol. Plant Pathol. 31, 83-90. doi: 10.1016/0885-5765(87)90008-7

Guidarelli, M., Carbone, F., Mourgues, F., Perrotta, G., Rosati, C., Bertolini, P., et al. (2011). Colletotrichum acutatum interactions with unripe and ripe strawberry fruits and differential responses at histological and transcriptional levels. Plant Pathol. 60, 685-697. doi: 10.1111/j.1365-3059.2010.02423.x

Guidarelli, M., Zoli, L., Orlandini, A., Bertolini, P., and Baraldi, E. (2014). The mannose-binding lectin gene FaMBL1 is involved in the resistance of unripe strawberry fruits to Colletotrichum acutatum. Mol. Plant Pathol. 15, 832-840. doi: $10.1111 / \mathrm{mpp} .12143$

Hardigan, M. A., Feldmann, M. J., Lorant, A., Bird, K. A., Famula, R., Acharya, C., et al. (2020). Genome synteny has been conserved among the octoploid progenitors of cultivated strawberry over millions of years of evolution. Front. Plant Sci. 10:1789. doi: 10.3389/fpls.2019.01789

Hardigan, M. A., Lorant, A., Pincot, D. D., Feldmann, M. J., Famula, R. A., Acharya, C. B., et al. (2021). Unraveling the complex hybrid ancestry and domestication history of cultivated strawberry. Mol. Biol. Evol. 38, 2285-2305. doi: 10.1093/molbev/msab024

Hurni, S., Scheuermann, D., Krattinger, S. G., Kessel, B., Wicker, T., Herren, G., et al. (2015). The maize disease resistance gene Htnl against northern corn leaf blight encodes a wall-associated receptor-like kinase. Proc. Natl. Acad. Sci. U. S. A. 112, 8780-8785. doi: 10.1073/pnas.1502522112

Jimenez, J. G. C. (2020). Strawberry Studies: Screening of Germplasm and Identification of Quantitative Trait Loci for Necrotrophic and Hemibiotrophic Resistance to Anthracnose Diseases, and Validation of a Set of SSR Fingerprinting Markers. dissertation/doctoral thesis. Raleigh (NC): North Carolina State University.

Kachroo, A., Venugopal, S. C., Lapchyk, L., Falcone, D., Hildebrand, D., and Kachroo, P. (2004). Oleic acid levels regulated by glycerolipid metabolism modulate defense gene expression in Arabidopsis. Proc. Natl. Acad. Sci. U. S. A. 101, 5152-5157. doi: 10.1073/pnas.0401315101

Kachroo, P., Venugopal, S. C., Navarre, D. A., Lapchyk, L., and Kachroo, A. (2005). Role of salicylic acid and fatty acid desaturation pathways in ssi2mediated signaling. Plant Physiol. 139, 1717-1735. doi: 10.1104/pp.105.071662

Kidd, B. N., Edgar, C. I., Kumar, K. K., Aitken, E. A., Schenk, P. M., Manners, J. M., et al. (2009). The mediator complex subunit PFT1 is a key regulator of jasmonate-dependent defense in Arabidopsis. Plant Cell 21, 2237-2252. doi: 10.1105/tpc.109.066910

Kim, S.-Y., and Volsky, D. J. (2005). PAGE: parametric analysis of gene set enrichment. BMC Bioinformatics 6:144. doi: 10.1186/1471-2105-6-144

Liu, M.-M., Xing, Y.-M., Zhang, D.-W., and Guo, S.-X. (2015). Transcriptome analysis of genes involved in defence response in Polyporus umbellatus with Armillaria mellea infection. Sci. Rep. 5:16075. doi: 10.1038/srep16075

MacKenzie, S., Legard, D., Timmer, L., Chandler, C., and Peres, N. (2006). Resistance of strawberry cultivars to crown rot caused by Colletotrichum gloeosporioides isolates from Florida is nonspecific. Plant Dis. 90, 1091-1097. doi: 10.1094/PD-90-1091

MacKenzie, S., Mertely, J., and Peres, N. (2009). Curative and protectant activity of fungicides for control of crown rot of strawberry caused by Colletotrichum gloeosporioides. Plant Dis. 93, 815-820. doi: 10.1094/PDIS-93-8-0815

Milholland, R. (1982). Histopathology of strawberry infected with Colletotrichum fragariae. Phytopathology 72, 1434-1439. doi: 10.1094/Phyto-72-1434

Mortazavi, A., Williams, B. A., McCue, K., Schaeffer, L., and Wold, B. (2008). Mapping and quantifying mammalian transcriptomes by RNA-Seq. Nat. Methods 5, 621-628. doi: 10.1038/nmeth.1226

Münch, S., Lingner, U., Floss, D. S., Ludwig, N., Sauer, N., and Deising, H. B. (2008). The hemibiotrophic lifestyle of Colletotrichum species. J. Plant Physiol. 165, 41-51. doi: 10.1016/j.jplph.2007.06.008

Nandi, A., Welti, R., and Shah, J. (2004). The Arabidopsis thaliana dihydroxyacetone phosphate reductase gene suppressor of fatty acid desaturase deficiencyl is required for glycerolipid metabolism and for the activation of systemic acquired resistance. Plant Cell 16, 465-477. doi: 10.1105/tpc.016907

Noh, Y.-H., Lee, S., Whitaker, V. M., Cearley, K. R., and Cha, J.-S. (2017). A high-throughput marker-assisted selection system combining rapid DNA extraction high-resolution melting and simple sequence repeat analysis: strawberry as a model for fruit crops. J. Berry Res. 7, 23-31. doi: 10.3233/ JBR-160145
Noh, Y.-H., Oh, Y., Mangandi, J., Verma, S., Zurn, J. D., Lu, Y.-T., et al. (2018). High-throughput marker assays for FaRPc2-mediated resistance to Phytophthora crown rot in octoploid strawberry. Mol. Breed. 38:104. doi: 10.1007/ s11032-018-0861-7

Oh, Y., Barbey, C. R., Chandra, S., Bai, J., Fan, Z., Plotto, A., et al. (2021). Genomic characterization of the fruity aroma gene, FaFAD1, reveals a gene dosage effect on $\gamma$-decalactone production in strawberry (Fragaria $\times$ ananassa). Front. Plant Sci. 12:639345. doi: 10.3389/fpls.2021.639345

Oh, Y., Chandra, S., and Lee, S. (2020). Development of subgenome-specific markers for FaRXf1 conferring resistance to bacterial angular leaf spot in allo-octoploid strawberry. Int. J. Fruit Sci. 20, 1-13. doi: 10.1080/15538362. 2019.1709116

Paolacci, A. R., Tanzarella, O. A., Porceddu, E., and Ciaffi, M. (2009). Identification and validation of reference genes for quantitative RT-PCR normalization in wheat. BMC Mol. Biol. 10:11. doi: 10.1186/1471-2199-10-11

Patkar, R. N., and Naqvi, N. I. (2017). Fungal manipulation of hormone-regulated plant defense. PLoS Pathog. 13:e1006334. doi: 10.1371/journal.ppat.1006334

Pinweha, N., Asvarak, T., Viboonjun, U., and Narangajavana, J. (2015). Involvement of miR160/miR393 and their targets in cassava responses to anthracnose disease. J. Plant Physiol. 174, 26-35. doi: 10.1016/j.jplph.2014.09.006

Rahman, M., and Louws, F. J. (2017). Epidemiological significance of crown rot in the fruiting field in relation to Colletotrichum gloeosporioides infection of strawberry nursery plants. Plant Dis. 101, 907-915. doi: 10.1094/ PDIS-06-16-0802-RE

Schenk, P. M., Carvalhais, L. C., and Kazan, K. (2012). Unraveling plant-microbe interactions: can multi-species transcriptomics help? Trends Biotechnol. 30, 177-184. doi: 10.1016/j.tibtech.2011.11.002

Singh, P., and Zimmerli, L. Z. (2013). Lectin receptor kinases in plant innate immunity. Front. Plant Sci. 4:124. doi: 10.3389/fpls.2013.00124

Smith, B. J. (2008). Epidemiology and pathology of strawberry anthracnose: a north American perspective. HortScience 43, 69-73. doi: 10.21273/ HORTSCI.43.1.69

Soto-Suárez, M., Baldrich, P., Weigel, D., Rubio-Somoza, I., and San Segundo, B. (2017). The Arabidopsis miR396 mediates pathogen-associated molecular pattern-triggered immune responses against fungal pathogens. Sci. Rep. 7:44898. doi: 10.1038/srep44898

Supek, F., Bošnjak, M., Škunca, N., and Šmuc, T. (2011). REVIGO summarizes and visualizes long lists of gene ontology terms. PLoS One 6:e21800. doi: 10.1371/journal.pone.0021800

Tan, G., Liu, K., Kang, J., Xu, K., Zhang, Y., Hu, L., et al. (2015). Transcriptome analysis of the compatible interaction of tomato with Verticillium dahliae using RNA-sequencing. Front. Plant Sci. 6:428. doi: 10.3389/fpls.2015.00428

Terry, L. A., Joyce, D. C., Adikaram, N. K., and Khambay, B. P. (2004). Preformed antifungal compounds in strawberry fruit and flower tissues. Postharvest Biol. Technol. 31, 201-212. doi: 10.1016/j.postharvbio.2003.08.003

Thimm, O., Bläsing, O., Gibon, Y., Nagel, A., Meyer, S., Krüger, P., et al. (2004). MAPMAN: a user-driven tool to display genomics data sets onto diagrams of metabolic pathways and other biological processes. Plant J. 37, 914-939. doi: 10.1111/j.1365-313X.2004.02016.x

Toljamo, A., Blande, D., Kärenlampi, S., and Kokko, H. (2016). Reprogramming of strawberry (Fragaria vesca) root transcriptome in response to Phytophthora cactorum. PLoS One 11:e0161078. doi: 10.1371/journal.pone.0161078

Verma, S., Bassil, N., Van De Weg, E., Harrison, R., Monfort, A., Hidalgo, J., et al. (2016). "Development and evaluation of the Axiom ${ }^{\circledR}$ IStraw35 384HT array for the allo-octoploid cultivated strawberry Fragaria $\times$ ananassa." in VIII International Strawberry Symposium (Belgium: ISHS Acta Horticulturae), 1156, 75-82.

Wang, F., Zhang, F., Chen, M., Liu, Z., Zhang, Z., Fu, J., et al. (2017). Comparative transcriptomics reveals differential gene expression related to Colletotrichum gloeosporioides resistance in the octoploid strawberry. Front. Plant Sci. 8:779. doi: $10.3389 /$ fpls.2017.00779

Whitaker, V. M., Knapp, S. J., Hardigan, M. A., Edger, P. P., Slovin, J. P., Bassil, N. V., et al. (2020). A roadmap for research in octoploid strawberry. Hortic. Res. 7:33. doi: 10.1038/s41438-020-0252-1

Whittaker, C. A., and Hynes, R. O. (2002). Distribution and evolution of von Willebrand/integrin A domains: widely dispersed domains with roles in cell adhesion and elsewhere. Mol. Biol. Cell 13, 3369-3387. doi: 10.1091/mbc. e02-05-0259

Xia, W., Yu, H., Cao, P., Luo, J., and Wang, N. (2017). Identification of TIFY family genes and analysis of their expression profiles in response to 
phytohormone treatments and Melampsora larici-populina infection in poplar. Front. Plant Sci. 8:493. doi: 10.3389/fpls.2017.00493

Xu, L., Zhu, L., Tu, L., Liu, L., Yuan, D., Jin, L., et al. (2011). Lignin metabolism has a central role in the resistance of cotton to the wilt fungus Verticillium dahliae as revealed by RNA-Seq-dependent transcriptional analysis and histochemistry. J. Exp. Bot. 62, 5607-5621. doi: 10.1093/jxb/err245

Zhang, Z., Feechan, A., Pedersen, C., Newman, M. A., Qiu, J. L., Olesen, K. L., et al. (2007). A SNARE-protein has opposing functions in penetration resistance and defence signalling pathways. Plant J. 49, 302-312. doi: 10.1111/j. 1365-313X.2006.02961.x

Zhang, L., Huang, X., He, C., Zhang, Q.-Y., Zou, X., Duan, K., et al. (2018). Novel fungal pathogenicity and leaf defense strategies are revealed by simultaneous transcriptome analysis of Colletotrichum fructicola and strawberry infected by this fungus. Front. Plant Sci. 9:434. doi: 10.3389/fpls.2018.00434

Zhang, L., Zhang, F., Melotto, M., Yao, J., and He, S. Y. (2017). Jasmonate signaling and manipulation by pathogens and insects. J. Exp. Bot. 68, 1371-1385. doi: $10.1093 /$ jxb/erw478
Conflict of Interest: The authors declare that the research was conducted in the absence of any commercial or financial relationships that could be construed as a potential conflict of interest.

Publisher's Note: All claims expressed in this article are solely those of the authors and do not necessarily represent those of their affiliated organizations, or those of the publisher, the editors and the reviewers. Any product that may be evaluated in this article, or claim that may be made by its manufacturer, is not guaranteed or endorsed by the publisher.

Copyright (0) 2021 Chandra, Oh, Han, Salinas, Anciro, Whitaker, Chacon, Fernandez and Lee. This is an open-access article distributed under the terms of the Creative Commons Attribution License (CC BY). The use, distribution or reproduction in other forums is permitted, provided the original author(s) and the copyright owner(s) are credited and that the original publication in this journal is cited, in accordance with accepted academic practice. No use, distribution or reproduction is permitted which does not comply with these terms. 